no other evidence discoverable. Inquest held; no medical testimony called. "Died by the visitation of God."

Three similar cases rapidly followed this one, and no medical man was examined in either case; but on the occurrence of the fourth, I wrote privatcly to the Coroner, and expressed my apprehension that all was not right, and that I had great suspicion of foul play. This is

CASE 3. - At the inquest the same tactic of the lawyer was exhibited:-- "Do you suspect, or have you any reason to believe, that __ died from foul treatment?" I replied, "Sir, I decline answering your question. I am not going to make myself the public prosecutor. It is your duty to ascertain the actual cause of cieath, and for the jury to judge if that was foul or natural." He altered several times the verbiage of the question, and, lastly, asked me if I felt competent professionally to form an opinion upon so simple a case? I remained immovable, and adhered to my reply. The Coroner refused an autopsy, handed me my guinea, and told me he was sorry I had given so little assistance to the jury. I left the room disgusted, when, in my absence, and without my knowledge or consent, the Coroner read my private note to him aloud before the jurv, and made severe comments on my unsuccessful efiorts to induce him to violate the sanctity of the grave!

CASE 4. - A poor boy, who had been most unmercifully beaten by his mother, was found dead a short time after that occurrence in a deep ditch full of water, just behind his father' sottage. I saw him shortly after the discovery of his corpse, vhich was covered with brerises! Inquest held; no medical evidence. Verdict, "Found drowned."

I am not the only medical man who, directly he hears of a corpse being found, turns his horse's head in an opposite direction, feeling certain that any inspection will entail a great deal of tronble, and end in one of the most remarkable burlesques which incapacity and arrogance can accomplish. 1 beg to suggest the formation of a committee to receive the names of all medical gentlemen ready to contest the next vacancies in their respective counties, cities, and boroughs; to obtain the co-operation of our brethren, and furnish arguments ready for promulgation amongst constituencies as occrsions may present themselves.

Nov. 1855 . I ain, Sir, your obedient servant,

P.S. - T enclose my name and address, which $T$ suppress only out of charity to the Coroner, who is at least, I fear, only a fair specimen of attorney coroners; yet I am quite ready to support my statements publicly.

\section{THE MEMORIAL OF THE ASSTSTANT- SURGEONS.}

To the Eclitor of THE TANCET.

SIR,-I have just receired THE LAxceT of October 13th, containing an article upon Dr. Andrew Smith and the memorial of the assistant-surgeons. As that article is extremely unfair in its tone and tendency, I beg you will allow one who has been through the whole campaign a portion of your space for a few observations upon it. I have read THE LANCET for many years, and its character has always been that of an untiring advocate for merit, however humble, and an unsparing assailant of all abuses, however sanetioned by usage or authority, calculated to degrade the profession or to perpetuate misrnle; but that article is so far from being in harmony with this character, that it has been publicly hinted here that it was composed in Dr. Smith's office; and it talks of a highly respectable and intelligent body of men in a contemptuous and slighting manner, as "only assistant-surgeens."

On your general eulogy on Dr. Smith's character, I am content to be silent; but it is confessedly owing to the tardiness of the Government in effecting their improvement of the Medical Department that he is still in his present position.

You state that our memorial is not sufficiently precise. In explanation, let me say, that we not only complain that we "are not promoted in equal proportion with our military companions," but we also "do impugn the present system upon which army medical officers are promoted"-a system which sanctions the promotion of men who have seen no service over the heads of those who have undergone the yet hardly realized privations and sufferings of this campaign-a system which allows service in the field to count for nothing more than the same service spent in the luxuries of a depot or a home-station.

With regard to the manner of transmitting the memorial, I may say that it was in the first instance sent in the regular 534 official manner through Dr. Hall and General Simpson. Having thus reached the War-office, and being seen to relate to medical affairs, it was forthwith handed to Dr. Smith, who returned it to us in the manner already well known. To prevent the recurrence of such an accident, and in justice to ourselves, the second time it was sent direct to Lord Panmure, and, to secure his seeing it, a copy was published in the newspapers, an act which Mr. Peel told us was a "grare impropriety." But, pray, what else could we have done? Either abandon the memorial altogether, or send it again in the same private official manner, to be again returned to us with a more severe reproof.

As these are the only points you have tonched upon in your article, I need take up no more of your valuable space.

Finally, you remark that " the assistant-surgeons possess in Dr. Andrew Smith a chief warmly attached to his profession, and anxious to promote the claims" \&c. If so, Dr. Smith has never attempted to institute a plan by which he may distinguigh between those who are professionally skilful and professionally ignorant; and during his tenure of office he has never done one single thing to advance his profession to its true position before the army and the public.

I am, Sir, your obedient servant,

Sebastopol, November, 185̃5. Assistant-SURGEON.

\section{ON THE PREVENTION OF GANGRENE FROM COLD.}

To the Editor of The Larcet.

SIn,-As your journal is circulated amongst the medical officers in the Crimea, perhaps you will allow me a short space for a suggestion which I made at the Medical Society of London on Saturday evening, when Dr. J. Bird read a paper on Traumatic Gangrene, and on Gangrene from Cold.

Many of our soldiers, as well as those of our allies, suffered much last winter from the effects of cold, especially in the feet. I believe, Sir, that most of these accidents would have been avoided if the following plan had been adopted; and as the present winter may be more severe than the last, I am induced to give it publicity in your journal :-

Let the feet be well rubbed with fat, or with oil, if this cannot be procured, and then covered with wash-leather socks, and over these the ordinary worsted stockings

Birds that are much exposed to cold have all, at this season of the year, a layer of fat under the skin; and it was the frequent observance of this that drew my attention to the matter. I did not know that the plan had ever been tried; but Dr. Bird, in his reply, mentioned a French surgeon who stated that " those who rubbed their noses and ears with goose-fat were not frost-bitten;" and another nember of the Society informed me " that the Russian peasants often rubbed their feet with tallow and oil to prevent the effects of cold."

Another most important adjunct would be a warm covering for the chest, and I know of nothing better than the skin of a water bird-the geese, ducks, and divers especially. These birds have been seen in great abundance in the Crimea, and probably shot; their skins can be readily taken off by making an incision along the back, and removing the wings and legs; the skin with the inner side towards the chest can easily be kept in its place by means of a piece of broad tape round the neck. Some of your readers will laugh at this, and others will say, like Mrs. Glass, first catch your goose; but I believe that the tame ducks and geese procured in large quantities at the farm-houses in the various sporting expeditions in the Crimea, if so used, would have been nearly as valuable for the table, and their skins of far greater benefit as articles of clothing.

November, 1855 ō. I am, Sir, your obedient servant, Edwards Crisp.

\section{ON THE ARTIFICIAL TYMPANUM. To the Editor of THE LANCET.}

SIR,-Those of your readers who have not seen my brochure on the Use of an Artificial Membrana Tympani, might imagine, after the perusal of Mr. Yearsley's recent letter, that I had omitted all notice of that gentleman's plan of applying cottonwool in cases of perforate membrana tympani. I therefore beg to say that when reciting the experiments I performed previous to using an artificial membrana tympani, I referred to $\mathrm{Mr}$. Yearsley's pamphlet, and the following paragraph has appeared in an appendix to every edition of my brochure:-

"In the year $1848 \mathrm{Mr}$. Yearsley published a pamphlet, en. 